Journal of the Scholarship of Teaching and Learning, Vol. 21, No. 2, June 2021, pp. 93-106. doi: 10.14434/josotl.v21i2.28723

\title{
Course Redesign: Implementing Project-Based Learning to Improve Students' Self-Efficacy
}

\author{
Masha Krsmanovic \\ University of Central Florida
}

\begin{abstract}
This research examined the effects of a first-year seminar course redesign on promoting students' self-efficacy. By implementing a project-based approach in the course curriculum, the study investigated if, and to what extent, did such redesign improve student belief in their ability to master course-related outcomes. Two-tailed independent samples t-test at an alpha level of .01 were conducted to answer the research question and compare self-efficacy of students who completed the course under the traditional curriculum $(n=821)$ and students who completed the course under the new curriculum $(n=881)$. The results revealed statistically significant differences in students' responses for all learning outcomes before and after the curriculum redesign.
\end{abstract}

Keywords: course redesign, project-based learning, self-efficacy, learning outcomes

\section{Introduction}

Increasing college enrollments represent one of the constants characterizing 21st century higher education. Colleges and universities have been open to a more heterogeneous body of students who, in addition to age, racial, and cultural diversity, present unique knowledge acquisition and intellectual curiosity. As Sternberg postulated: "A strange new breed of students has invaded our universities. They either bring new and unique ways of learning and will change higher education forever or they are intent on intellectual Armageddon" (2012, p. 571). Whether perceived as a declaration of innovative college-level instruction or caution against its resistance, this statement undoubtedly embodies the major construct underlying the future direction of the scholarship of teaching and learning - the distinctiveness of learners' academic attributes.

According to Fink (2013), both individuality and diversity among modern learners lead to different methods of inquiry, different models of thinking, and ultimately, different ways of learning. Additionally, students enroll in college with different personal and professional goals; thus, forming different expectations about the desired learning outcomes. For instance, modern learners were found to have a strong preference toward hands-on learning, collaboration, and instructional technology (Shaw \& Fairhurst, 2008), experiential learning (Pardue \& Morgan, 2008), and problem-based learning (Rickes, 2009). As a result, educators are expected to shift the traditional role of intellectual authorities and become learning facilitators (Rickes, 2009).

A substantial body of literature has examined the effectiveness of varied strategies that faculty have implemented to attend to these preferences. It is generally accepted that the efforts invested in course design, for the most part, have had positive effects on many aspects of student learning. The major effects of curricular redesigns include improving student academic performance (Hearne \& Henkin, 2011, Wilson et al., 2018) and student satisfaction with learning experience (Das et al., 2019; Vaughan, 2010). Additionally, students who completed a redesigned section of a course improved in the domains of active and collaborative learning (Vaughan, 2010), and intellectual engagement and attendance (Das et al., 2019). Finally, the long-term benefits of redesigned courses have been found to be maintained and sustained over time (Rosenthal \& Weitz, 2012).

At the same time, however, the scholarly efforts in this direction remain limited in two important aspects. First, less evidence exists on the relationship between course redesign initiatives 
and a powerful predictor of students' academic success - self-efficacy (Lynch, 2006). Students' belief in whether or not they can accomplish an academic task was identified as highly associated with their decision to bounce back from negative academic experiences and persist despite academic difficulties (Komarraju \& Nadler, 2013). Still, a gap remains in research assessing whether a course redesign can promote students' academic self-efficacy and, ultimately, their persistence.

Second, course redesign efforts assessed in the literature have usually been guided by a particular and narrowly defined set of innovative approaches aimed at substituting traditional teaching methods. These approaches included technology and digital learning (Hearne \& Henkin, 2011; Wilson et al, 2018), active learning strategies (Nomme \& Birol, 2014), flipped classroom (Das et al, 2019), and blended learning (Vaughan, 2010). Still, using project-based learning in a course design remains among teaching and learning approaches whose effects have not been comparably explored.

Despite the rich findings in the literature in the domain of course redesign, the question remains as to whether a project-based teaching and learning approach can be used to promote student self-efficacy for course learning outcomes. To address this limitation, this study examined the effects of a first-year seminar course redesign on promoting participants' self-efficacy. Specifically, this study examined the following research question: did the first-year seminar course redesign and the implementation of project-based learning change students' self-efficacy for any of the seven learning outcomes as defined by the course syllabus: (1) application of research-proven study strategies, (2) confidence in performing college-level tasks, (3) understanding the connection between academic success and motivation, (4) setting effective goals, (5) understanding the elements of good decisionmaking, (6) analyzing the use of time with one's goals, and (7) engaging in career exploration.

\section{Literature Review}

\section{Course Redesign}

The effects of course redesign have received considerable scholarly attention in recent years. Many researchers studied if and how the innovations in course curricula, instructional delivery, or pedagogy can promote student learning. Unsurprisingly, the central issue in this inquiry remained the relationship between course redesign and student academic achievement. Specifically, research shows that, compared to their peers in traditional class sections, students in redesigned courses learned more and achieved higher grades (Hearne \& Henkin, 2011; Vaughan, 2010; Wilson et al., 2018). Interestingly, students in treatment groups with redesigned curricula not only outperformed their peers in traditional course sections who had higher high-school GPA and SAT scores (Aitken, 2005), but also those enrolled in smaller classes with smaller student-faculty ratios (Hearne \& Henkin, 2011). Additionally, students in the redesigned sections also surpassed their peers with initially higher performance in the same course (Wilson et al., 2018).

Scholarly inquiries have also been directed toward understanding the effects of course redesign on student satisfaction with not only the class but also the overall learning experience. This research has provided evidence that changes in course curricula and instructional delivery led to increased student satisfaction with academic experience (Das et al., 2019; Vaughan, 2010) and faculty satisfaction with the new mode of instruction (Rosenthal \& Weitz, 2012). Other benefits included participants' increased engagement in active and collaborative learning (Vaughan, 2010), intellectual engagement (Das et al., 2019), improved well-being and self-reflection (Everett, 2013), and development of grit, tenacity, and perseverance (Olson, 2017).

Journal of the Scholarship of Teaching and Learning, Vol. 21, No. 2, June 2021. josotl.indiana.edu 


\section{First-Year Seminar Courses}

First-Year Seminar (FYS) courses represent one of the most prevalent educational practices employed by higher education institutions to promote student performance, retention, and graduation. According to the 2017 national survey on the first-year experience, $74 \%$ of 537 responding institutions implemented this high-impact practice (NRC, 2019). In terms of the course objectives, academic success strategies constituted the most popular learning outcome, followed by connecting students with the institution, and knowledge of resources. Nationally, FYSs were more prevalent among fouryear universities than two-year colleges, with approximately equal distribution among public and private institutions. Almost half of the seminars followed the structure of an academic-themed course and prioritized the development of students' academic skills and competences. Other prominent designs included extended-orientations and professional or discipline-specific courses. Most commonly, the seminars counted as either 1-credit or 3-credit hours.

Among the extensive contemporary research on the seminar impacts, most scholarly interest has been devoted to their role in improving students' academic performance and retention. With that regard, recent empirical evidence has demonstrated that FYSs effectively promoted students' GPA within the first semester (Karp et al., 2017; Swanson et al., 2017) and first year (Permzadian \& Crede, 2016). In terms of retention, most evidence has been produced for course effects on improving students' progress to second semester (Karp et al., 2017; Vaughan et al., 2014), second year (Cambridge-Williams, 2013; Karp et al., 2017; Pittendrigh et al., 2016;) and third year (Swanson et al., 2017).

Simultaneously, the research on the seminars has been extending beyond their effects on performance and retention to include a wide range of academic skills and competencies critical for students' academic, professional, and personal development. The most prominent examples in this domain include the course potency to facilitate contextualized and applied learning (Swanson et al., 2017), improve metacognition and self-regulation (Hoops \& Artrip, 2016; Steiner et al., 2019), promote writing and research skills (Birol et al., 2013; Stebleton \& Jehangir, 2016), and cultivate information literacy (Murray \& Lachowsky, 2016).

\section{FYS Course Redesign}

Of particular interest for this study is prior research noting the benefits of FYS course redesign and the effects of implementing curricular changes to promote the attainment of learning outcomes. For instance, Woolfork-Barnes (2017) observed that students attending themed FYS sections (i.e. sections redesigned for particular majors) performed better academically, measured by a higher semester GPA. Similarly, Tampke and Durodoye (2013) recorded that redesigning a FYS course for undecided students using a learning community model led to improved GPA and academic standing. Other authors, like Ryan (2013), examined the benefits of intentionally selecting and assigning FYS faculty to particular course sections. The results indicated improved GPA and retention for students taught by specially trained academic advisors, compared to participants taught by regular instructors (i.e. nonadvisors).

Much attention has also been devoted to the benefits of redesigning FYS courses by introducing authentic assessment. For example, Everett (2013) demonstrated that incorporating a reflective journal writing in course curriculum can result in improved well-being, self-reflection, and time-management, while Olson (2017) confirmed the benefits of introducing intentional assignments for the development of students' grit, tenacity, and perseverance. Regardless of the type of redesign initiatives, the research provides ample evidence that intentionally restructuring FYS to meet specific learning goals can lead to a strong positive effect on student outcomes.

Journal of the Scholarship of Teaching and Learning, Vol. 21, No. 2, June 2021. josotl.indiana.edu 


\section{Project-based Learning}

The teaching and learning approach popularly referred to as project-based learning (PjBL) represents a more recent phenomenon that has not yet produced the assessment, evaluation, and validation evidence equivalent to that of first-year seminars or course redesign. The most succinct definition of project-based learning would be that it represents a model that organizes learning around projects (Thomas, 2000). Other defining characteristics that appeared in the early literature included authentic assessment and teacher-facilitated instruction (Moursund, 1999), cooperative learning and reflection (Diehl et al., 1999), and community of inquiry and use of technology-based tools (Krajcik et al., 1994). Contemporary resources most commonly define PjBL as student-centered and participant-directed learning from personal experience and activity (De Graaff \& Kolmos 2003; Steenhuis \& Rowland, 2018). Additionally, such learning is considered interdisciplinary and transferable, as well as collaborative and team-based (Graaff \& Kolmos, 2007; Steenhuis \& Rowland, 2018).

This heterogeneity of PjBL characteristics and the absence of a universally adopted PjBL model leads to not only numerous variations in implementing this approach, but also to challenges in assessing its effects (Thomas, 2000). As a result, the growing interest in and implementation of PjBL in college-level instruction were not accompanied by equal attempts to assess its effects on student learning outcomes. The available studies, however, agree that $\mathrm{PjBL}$ can be used as a powerful tool to improve student learning. The most pronounced positive effects have been recorded in the domain of academic performance (C,elik et al., 2018; Huysken et al., 2019) and motivation (Amaral et al., 2018; Requies et al., 2018). Additional results have been documented for improving students' conceptual understanding (Coruhly \& Nas, 2018), advancing research skills (Saliba et al., 2017), and enhancing participants' self-efficacy, teamwork, and communication skills (Fini et al, 2018).

As can be seen, both course redesign and project-based learning have attracted a wide scholarly interest regarding their effects on student learning outcomes. Simultaneously, FYSs have steadily emerged as a research-proven tool for supporting undergraduate student academic progress and learning. Following the scholarly traditions in all three domains - course redesign, FYSs, and PjBL, this study aimed to bridge and advance the existing empirical knowledge by providing new insights on the possible ways in which the FYS course curriculum, design, and instruction can be improved by implementing PjBL.

\section{Current Study}

The course in which participants were enrolled is a 3-credit hour academic-themed first-year seminar, designed to support students' academic integration and performance. The course is taught in a small classroom setting of up to 35 students, with classes meeting two times a week for 75 minutes. Even though the course is offered during the entire academic year, the greatest student enrollment takes place in summer. As an illustration, 57\% of FYS participants enrolled in summer, 34\% in fall, and only $9 \%$ in the spring of 2018 .

The course faculty represent a wide variety or ranks, disciplines, and professional experiences. Approximately 40 faculty members who teach the course each year are comprised of full-time faculty from other departments and schools at the institution (mainly humanities and social sciences), adjunct faculty from nearby colleges and universities, and academic affairs professionals employed at the institution (primarily academic advisors and career services staff).

As an academic-themed seminar, the primary goal of the course is to promote students' development of academic skills and competences. The learning outcomes for the course were designed to support this objective and were identified as follows: (1) applying research-proven study strategies;

Journal of the Scholarship of Teaching and Learning, Vol. 21, No. 2, June 2021. josotl.indiana.edu 
(2) increasing confidence in performing college-level tasks; (3) understanding the connection between academic success and motivation; (4) setting effective goals; (5) understanding the elements of good decision-making, (6) analyzing the use of time with one's goals; and (7) engaging in the career exploration process.

The traditional course curriculum of the FYS examined in this study involved the assessment of student learning for each outcome through conventional methods such as written reflections and papers, online quizzes, and in-class exams. In spring 2017, the course redesign committee, consisting of the program coordinator and three instructors, met to discuss possible ways in which student learning could be promoted by revising the traditional assessment measures. After numerous bi-weekly meetings, the committee agreed to redesign the course assessment by implementing Fink's (2013) forward-looking assessment and Wigging's (1998) authentic performance tasks.

Both forward-looking assessment (Fink, 2013) and authentic performance tasks (Wigging, 1998) refer to creating assignments that are authentic, realistic, require creative thinking, simulate realistic real-life challenges, and enable students to become active participants in the learning process. To provide FYS students with this type of learning experience, the major assignments in the course were considerably revised in line with the authentic assessment and PjBL (Wigging, 1998; Fink, 2013). In spring 2017, the committee redesigned each of the traditional course assignments and implemented new authentic assessments in summer 2018. Table 1 presents the overview of major assessments that were used in spring 2017 and the redesigned assessments that were introduced in summer 2018.

Table 1: Traditional and redesigned assessment activities for each learning outcome.

\begin{tabular}{lll}
\hline Learning Outcome & $\begin{array}{l}\text { Traditional Assessment } \\
\text { Summer 2018 }\end{array}$ & $\begin{array}{l}\text { Redesigned Assessment } \\
\text { Summer 2018 }\end{array}$ \\
\hline & $\begin{array}{l}\text { Part 1: Write a 3-page paper } \\
\text { summarizing three peer-reviewed } \\
\text { research articles related to college } \\
\text { student success. }\end{array}$ & $\begin{array}{l}\text { Part 1: Write a 3-page paper applying the } \\
\text { information from three peer-reviewed } \\
\text { research articles related to college student } \\
\text { success. } \\
\text { Ppply research-proven study } \\
\text { strategies and increase confidence } \\
\text { in performing college-level tasks }\end{array}$ \\
$\begin{array}{lll}\text { Part 2: Prepare and deliver a } \\
\text { PowerPoint presentation on the } \\
\text { summarized articles. }\end{array}$ & $\begin{array}{l}\text { available campus services and resources } \\
\text { related to the topics discussed in the } \\
\text { articles. } \\
\text { Part 3: In small groups, develop a poster } \\
\text { illustrating the applicability of the }\end{array}$ \\
& & information from the articles.
\end{tabular}

\begin{tabular}{lll}
\hline $\begin{array}{l}\text { Understand the connection } \\
\text { between academic success and } \\
\text { motivation }\end{array}$ & $\begin{array}{l}\text { Write a 2-page "college journey" } \\
\text { reflection discussing the motivators } \\
\text { to enroll and persist in college. }\end{array}$ & $\begin{array}{l}\text { Complete a GPA calculation worksheet in } \\
\text { the mid-semester and apply motivational } \\
\text { theories to identify what, if any, factors } \\
\text { may be affecting students' motivation and } \\
\text { academic performance }\end{array}$ \\
\hline & $\begin{array}{l}\text { Develop a goal-setting worksheet } \\
\text { illustrating goals for each year of students' } \\
\text { Urite a 2-page reflection paper } \\
\text { discussing students' academic goals }\end{array}$ & $\begin{array}{l}\text { timeline, students identify one academic } \\
\text { or career goal and develop interim short- } \\
\text { term goals by applying the ABCS } \\
\text { framework: (A) Aim high, (B) Believe in } \\
\text { yourself, (C) Care and commit, and (S) }\end{array}$ \\
& $\begin{array}{l}\text { Specify and self-reflect. } \\
\end{array}$
\end{tabular}

Journal of the Scholarship of Teaching and Learning, Vol. 21, No. 2, June 2021. josotl.indiana.edu 


\begin{tabular}{lll}
\hline Understand the elements of good & $\begin{array}{l}\text { Complete an online quiz related to } \\
\text { factors contributing to good } \\
\text { decision-making }\end{array}$ & $\begin{array}{l}\text { Participate in an in-class Social Issues } \\
\text { Debate and justify students' ethical and } \\
\text { other decision-making processes related } \\
\text { to social justice issues. }\end{array}$
\end{tabular}

\begin{tabular}{lll} 
Analyze the use of time with one's & $\begin{array}{l}\text { Keep a time diary for two weeks } \\
\text { and write a 2-page paper discussing } \\
\text { students' use of time. }\end{array}$ & $\begin{array}{l}\text { Develop a co-curricular worksheet } \\
\text { illustrating students' campus involvement } \\
\text { for each year of undergraduate studies. } \\
\text { Students account for the time they will } \\
\text { dedicate to campus and community-based } \\
\text { involvement related to their previously } \\
\text { identified personal, academic, and career } \\
\text { goals. }\end{array}$ \\
\hline $\begin{array}{ll}\text { Independently engage in the career } \\
\text { exploration process. }\end{array}$ & $\begin{array}{l}\text { Write a 3-page paper on the topic } \\
\text { of students' intended career, } \\
\text { discussing job description, tasks, } \\
\text { outlook, salary, work environment, } \\
\text { opportunities for advancement, } \\
\text { education, and other requirements. }\end{array}$ & $\begin{array}{l}\text { Part 1: Attend the career-services resume- } \\
\text { building workshop. } \\
\text { Part 2: Develop a resume. } \\
\text { Part 3: Video record an elevator pitch } \\
\text { curricular accomplishments. }\end{array}$
\end{tabular}

The committee implemented Fink's (2013) forward-looking assessment and Wigging's (1998) authentic performance tasks with the hopes of accomplishing several outcomes. First, the authentic assessment was designed to provide course participants with opportunities to apply the acquired knowledge to real-life situations and incorporate personal experience, both of which are principal characteristics of PjBL (De Graaff \& Kolmos 2003; Steenhuis \& Rowland, 2018). Next, by being asked to develop real-life projects (e.g. resume, elevator pitch, goal-setting worksheets) and display creativity in applying the gained knowledge (e.g. debates and poster sessions), students were encouraged to embrace the roles of active learners and co-constructors of knowledge. This focus was guided by the perennial definition of $\mathrm{PjBL}$ as a model that organizes learning around projects (Thomas, 2000). Even though students did not engage in realistic situations, they were still presented with an opportunity to gain valuable learning practice by replicating real-life contexts. The goal behind such an approach was to make students' work purposeful, practical, and applicable to real-life situations.

Additionally, the revised assessments were also designed to allow the course participants to undertake increased responsibility for their intellectual inquiry and to direct their own learning. By making assessments interdisciplinary, collaborative, and team-based, the redesigned course embraced pivotal attributes of PjBL (Graaff \& Kolmos, 2007; Steenhuis \& Rowland, 2018) and empowered students to become co-constructors of knowledge. By actively seeking knowledge in a real-life context that is personally meaningful to them, students were allowed to develop self-efficacy for applying the knowledge in the contexts of their academic and personal lives.

\section{Method}

Setting

This study was conducted at a large, public, research institution in the southeast. At the time of the study, the total undergraduate population at the institution exceeded 50,000. First First-Time in College (FTIC) students comprised nearly $20 \%$ of the total undergraduate enrollment. The research

Journal of the Scholarship of Teaching and Learning, Vol. 21, No. 2, June 2021. josotl.indiana.edu 
setting was also characterized by diverse student representation, with approximately $48 \%$ White, $26 \%$ Hispanic, 11\% Black, and 6\% of Asian students.

\section{Data Collection}

Due to the non-random participant assignment and students' self-enrollment in the FYS course, this research was designed as a quasi-experimental comparison study (Gall et al., 2008). The total sample included 965 students enrolled in the course in summer 2017 and 1,130 students enrolled in summer 2018. Of this sample, 821 students completed the survey in summer 2017 (85\% response rate) and 881 students responded in summer 2018 (78\% response rate). The survey was distributed to students during the last class meeting. As per the Institutional Review Board, first-year students who were under 18 at the time of the research did not participate in the study.

\section{Measures}

Dependent variables in this study included seven learning outcomes as identified by the course syllabus (1) application of research-proven study strategies, (2) confidence in performing college-level tasks, (3) understanding the connection between academic success and motivation, (4) setting effective goals, (5) understanding the elements of good decision-making, (6) analyzing the use of time with one's goals, and (7) engaging in career exploration. The independent variable was the group assignment: the control group (traditional curriculum, Summer 2017) versus the comparison group (redesigned curriculum, Summer 2018).

The survey instrument consisted of seven Likert scale questions corresponding to each learning outcome. All dependent variables were assessed through a single statement: "Please choose the response that best describes your confidence level for the following learning outcomes." The responses included: (1) not at all confident, (2) somewhat confident, (3) moderately confident, (4) highly confident, and (5) extremely confident.

\section{Results}

Two-tailed independent samples t-test at an alpha level of .01 were conducted to answer the research question and compare self-efficacy of students who completed the course under the traditional curriculum $(\mathrm{n}=821)$ and students who completed the seminar under the new curriculum $(\mathrm{n}=881)$. Levene's test of equality of variance was performed for all seven variables (i.e. learning outcomes). In four of the seven variables, the assumption of equal variance was not violated, and a t-test with equal variances assumed was reported. For the remaining three variables, the equal variance was not assumed, and a t-test with equal variances not assumed was reported.

The results revealed statistically significant differences in students' responses for all learning outcomes before and after the curriculum redesign. Table 1 presents descriptive and inferential statistics, including means and standard deviation scores for the seven learning outcomes, as defined by the course syllabus.

The greatest difference was recorded for students' self-efficacy in applying research-proven study strategies $\left(M_{1}=3.855, M_{2}=4.098, p<.001, t=6.665\right)$ and the smallest difference was identified for students' belief in their ability to understand the connection between academic success and motivation $\left(M_{1}=4.421, M_{2}=4.581, p<.001, t=4.636\right)$. Although there was a significant change between the two semesters for all seven learning outcomes, the effect sizes for the outcomes were small (Cohen, 1998).

Journal of the Scholarship of Teaching and Learning, Vol. 21, No. 2, June 2021. josotl.indiana.edu 
Table 2: Descriptive and inferential statistics.

\begin{tabular}{lllllll}
\hline Learning Outcome & Curriculum & $M$ & $S D$ & $t$ & $p$ & $d$ \\
\hline Ability to apply research-proven study & Traditional & 3.855 & .779 & 6.665 & $<.001$ & .324 \\
strategies & Redesigned & 4.098 & .718 & & & \\
\hline Confidence in performing college- & Traditional & 4.144 & .769 & 5.817 & $<.001$ & .282 \\
level tasks & Redesigned & 4.348 & .677 & & & \\
\hline Understanding the connection & Traditional & 4.421 & .768 & 4.636 & $<.001$ & .226 \\
between academic success and & Redesigned & 4.581 & .640 & & & \\
motivation & Traditional & 4.295 & .840 & 4.335 & $<.001$ & .212 \\
\hline \multirow{2}{*}{ Setting effective goals } & Redesigned & 4.461 & .722 & & & \\
\hline Understanding the elements of good & Traditional & 4.193 & .831 & 5.126 & $<.001$ & .249 \\
decision-making & Redesigned & 4.386 & .714 & & & \\
\hline Analyzing the use of time with one's & Traditional & 4.118 & .868 & 4.627 & $<.001$ & .225 \\
goals & Redesigned & 4.304 & .782 & & & \\
\hline \multirow{2}{*}{ Learning more about career-interests } & Traditional & 4.006 & .870 & 5.774 & $<.001$ & .283 \\
& Redesigned & 4.241 & .790 & & & \\
\hline
\end{tabular}

\section{Discussion and Implications}

This study sought to determine the effects of implementing PjBL in a FYS course redesign to improve students' self-efficacy. In doing so, this research study demonstrated that project-based learning and authentic assessment, designed as a realistic simulation of real-life challenges, can change students' confidence in their academic abilities. Namely, substituting traditional class projects such as quizzes, papers, and presentations, with authentic tasks like collaborative assignments, debates, and experiential learning activities, significantly changed students' perceptions about their abilities to successfully master the learning outcomes behind these activities. Overall, the results of this study demonstrated that the redesigned course curriculum significantly improved participants' belief in their ability to be active agents of their learning and knowledge acquisition. The results of the study contribute to the theory and practice of student learning and development in several important ways.

First, prior research has already documented that effective course redesign can improve student academic performance (Hearne \& Henkin, 2011, Wilson et al., 2018) and satisfaction with learning experience (Das et al., 2019; Vaughan, 2010). However, prior studies have not offered any insights into why such improvements may have taken place. Thus, the findings of this study can help us better understand the positive effects of prior course redesign efforts (Hearne \& Henkin, 2011; Vaughan, 2010; Wilson et al., 2018) by associating them with improvements in students' self-efficacy (Fini et al, 2018). It can also be argued that the evidence presented in this study supports the claim that students' perceptions of their increased academic abilities are not unwarranted and can be affirmed by their academic performance in the future (C,elik et al., 2018; Das et al., 2019; Huysken et al., 2019; Olson, 2017). This knowledge can serve as an important implication for all FYS faculty and staff working with students who are struggling academically, enroll in colleges under-prepared, or find it particularly hard to overcome academic barriers and roadblocks. Knowing that academic selfefficacy promotes students' ability to bounce back from negative academic experiences (Komarraju \& 
Nadler, 2013), first-year course designers can use this study as a blueprint for helping participants develop this important skill through project-based and authentic tasks.

The next contribution of this research pertains to the impacts of PjBL on the improvement of students' academic self-efficacy. While previous studies have demonstrated the benefits of PjBL in improving student academic performance (C,elik et al., 2018; Huysken, et al., 2019), conceptual understanding (Coruhly \& Nas, 2018), and research skills (Saliba et al., 2017), this study revealed its effects on participants' self-efficacy - a critical contributor to academic success. This finding of the current study can assist first-year academic coordinators and faculty to more efficiently utilize PjBL in their course redesign efforts, especially for accomplishing the learning outcomes that students' have historically struggled with.

The third contribution of this study was to empirically illustrate how the main characteristics of PjBL, as defined by the literature, may translate into improved student outcomes. Since its early definitions at the beginning of $21^{\text {st }}$ century and throughout the modern literature, PjBL has been perceived as the acquisition of knowledge and skills through real-world application, personal experience, self-reflection, collaboration, and, most importantly, authentic assessment (De Graaff \& Kolmos 2003; Diehl et al., 1999; Moursund, 1999; Steenhuis \& Rowland, 2018; Thomas, 2000). Comparably, the participants in this study constructed knowledge working in groups, became partners in the teaching and learning processes, applied knowledge to realistic and real-life scenarios, and demonstrated acquired skills through authentic assignments (Fini et al, 2018; Graaff \& Kolmos, 2007; Steenhuis \& Rowland, 2018). Both Fink (2013) and Wiggins (1998), whose work served as the framework for the course redesign initiative, argued that allowing students to actively seek knowledge in the real-life context and assessing their learning through authentic performance tasks can significantly increase their self-efficacy for applying their knowledge to academic and personal lives. As demonstrated by the findings of this study, this premise still holds true.

Beyond the realms of FYS courses and project-based learning, this research has confirmed that college students still display strong preferences toward hands-on learning and collaboration (Shaw \& Fairhurst, 2008), as well as experiential learning (Pardue \& Morgan, 2008). In this study, these preferences were demonstrated though participants' engagement in authentic assignments (e.g. resume, elevator pitch, debate, GPA calculation) and experiential tasks (e.g. visiting career-services, applying research projects to their academic careers, developing co-curricular engagement plan).

Additionally, the participants in this study confirmed that college students expect their instructors to be facilitators of learning, rather than intellectual authorities (Rickes, 2009). In the redesigned sections of the FYS course, all instructors adopted the roles of moderators (e.g. debates), learning guides (e.g. resume and elevator pitch projects), coordinators (visit to career services), or facilitators (e.g. co-curricular and GPA worksheets). Shifting the focus from instructors' expertise, authority, and control helped students embrace their learning agency and develop the necessary academic confidence. This finding serves as a critical implication for all faculty teaching not only firstyear seminars but all first-year students who are yet to build their academic self-efficacy. Prior research has already illustrated that the selection and competence of FYS instructors can have a significant impact on participants' academic performance (Ryan, 2013). Thus, first-year program developers can apply these results to enrich their training and professional development programs in a way that would best empower the course faculty to embrace the instructional roles that are most conducive to student learning. As documented by the findings in this study, FYS faculty play a pivotal role in the development of students' self-efficacy. As such, they need to carefully balance their roles of experts with those of facilitators, guides, and helpers. The overall recommendation in this regard reflects a need for training FYS faculty in a way that would help them achieve this balance and promote students' learning agency. At the time of this study, the FYS program did not offer any separate training for the

Journal of the Scholarship of Teaching and Learning, Vol. 21, No. 2, June 2021. josotl.indiana.edu 
faculty teaching the redesigned course sections, other than the mandatory pre-semester orientation. Consequently, the results of this study will serve as a blueprint for the upcoming faculty training and professional development programs.

The overarching contribution of this study is reflected in bridging two disparate research areas - the research regarding first-year seminar course redesign and the research on project-based learning. Based on this study, FYS courses should be regarded as a critical tool aimed to develop and promote an important predictor of student success - academic self-efficacy. Additionally, the study findings illustrate the necessity for first-year programs to design their seminars as student-directed learning experiences where participants can apply their knowledge and skills to real-life, authentic, and realistic tasks.

As documented by this research, there are two focus areas in which the FYS course curricula can be improved to better meet the academic needs of incoming students. First, increased attention needs to be added to students' interests, experiences, and prior knowledge. Second, the curriculum needs to promote student engagement with campus resources and provide opportunities for experiential learning and project-based assignments. Consequently, through targeted instruction and strategic course design, first-year students will be given more agency in their knowledge exploration and acquisition.

\section{Limitations and Future Research}

Even though the results revealed positive effects of FYS redesign, the study was also characterized by several limitations that must be acknowledged. The first and main limitation of this study is reflected in its design and the fact that the data were self-reported. As Gonyea (2005) noted, self-reported data are particularly problematic for estimating the net impact of a particular educational practice. Even though scholars agree that the use of self-reported estimates is sometimes warranted in educational research, it should not be considered a substitute for objective measures of student learning. At the same time, the nature of the research question examined in this study justifies the use of self-reported data. Assessing students' self-efficacy or their belief in their academic ability would have been hard to accomplish by other objective measures.

Next, as Cole et al. (2012) pointed out, survey research is additionally vulnerable to the practice of straight-lining or the respondents' tendency to selects the same response option for a set of items, thus creating the visual appearance of a "straight-line" (p. 2). However, their research indicated that straight-lining rarely occurs within early survey items and becomes more prevalent with the length of the survey. Given that the survey instrument in this study consisted of only seven items, Cole at al., (2012) finding allows us to assume that straight-lining had not been as prevalent in this data set. Also, Cole et al. (2012) further found that the prevalence of straight-lining increases with each survey invitation that is sent to potential respondents. The fact that this survey was distributed only once further reduces the possibility that straight-lining had occurred. To overcome the limitations caused by the research design, future studies should investigate the effects of FYS course redesign and PjBL on students' learning gains, such as course grades, GPA, or other objective measures of academic performance.

Further, the random assignment of participants to control and comparison groups was not viable in this study. Thus, it is possible that the differences observed between the two groups could be due to other variables not accounted for in this research. In that regard, additional investigation is required to examine the course redesign impacts while reducing the bias created by nonrandom assignment (e.g. controlling for students' demographics, academic readiness, or GPA). Additionally, even though the independent t-test revealed significant changes in students' self-efficacy between the two semesters for all seven learning outcomes, the effect sizes for the outcomes were small (Cohen,

Journal of the Scholarship of Teaching and Learning, Vol. 21, No. 2, June 2021. josotl.indiana.edu 
1998). This limitation becomes even more apparent in the light of Wise and Shaffer's (2015) reminder that large data sets are likely to yield statistical significance while carrying less practical significance. Thus, they proposed theory-informed decision making or relying on theory as "a coherent and reasoned framework from which to make decisions... in interpreting results and identifying meaningful, actionable results" (p. 6).

The next limitation is reflected in the fact that even though the composition of the faculty members teaching the traditional and the redesigned class sections was similar, it was not the same. Thus, it is possible that the observed effects can be attributable to FYS instructors' teaching styles and pedagogical approaches. Replicating the study while controlling for this variable and comparing the groups taught by the same instructors could help resolve this limitation. Additionally, it would be valuable to examine the perceptions and experiences of course faculty who had the opportunity to teach the course before and after the curriculum design initiative.

Lastly, the study took place at only one university and examined the redesign of one type of FYS. Therefore, generalization to other institutions and FYS programs is limited. The content, structure, credit-value, learning outcomes, and delivery of FYS courses all differ from campus to campus. Consequently, future research needs to be conducted at different colleges and universities and among different FYS types to learn if the course redesign initiative would be as beneficial as in this research.

\section{Conclusion}

Designing innovative curricular approaches to increase student performance is a complex task involving thorough consideration of various contextual factors. Even though the assessment of such innovations can be a challenging task due to numerous factors underlying both the process of innovation and the evaluation of its effects, this study attempted to contribute to the field by assessing the impacts of PjBL curricular enhancement on students' self-efficacy.

In conclusion, the findings of this research produced several implications for faculty and administrators involved in first-year curricular planning. As such, the proposed platform can be used to stimulate students' self-efficacy through active learning strategies that would not sacrifice content coverage. In that regard, this research suggests that $\mathrm{PjBL}$ serves as an effective method in helping students relate FYS materials to practice while improving their belief in the ability to apply the course content. Knowing that early success in college coursework can have a substantial impact on students' performance throughout their undergraduate career was the central premise of this course redesign initiative. Guided by that aim, this research produced a practical outline of the lessons learned in the process intended to guide scholars and practitioners who wish to undertake similar curricular innovations in the future.

\section{References}

Aitken, N. D. (2005). The large lecture course redesign project: Pedagogical goals and assessment results. College Teaching Methods \& Styles Journal, 1(2), 61-68. https://eric.ed.gov/?id=EJ966432

Amaral, J. A. A., Araujo, C. R. M., \& dos Santos, R. J. R. L. (2018). Lessons learned implementing project-based learning in a multi-campus blended learning environment. Journal of ProblemBased Learning in Higher Education, 6(2), 1-31. https:/ / doi.org/10.5278/ojs.jpblhe.v6i2.1928

Birol, G., Han, A., Welsh, A. \& Fox, J. (2013). Impact of a first-year seminar in science on student writing and argumentation. Journal of College Science Teaching, 43(1), 82-91. https://www.jstor.org/stable/43631725

Journal of the Scholarship of Teaching and Learning, Vol. 21, No. 2, June 2021. josotl.indiana.edu 
Cambridge-Williams, T., Winsler, A., Kitsantas, A. \& Bernard, E. (2013). University 100 orientation courses and living-learning communities boost academic retention and graduation via enhanced self-efficacy and self-regulated learning. Journal of College Student Retention: Research, Theory \& Practice, 15(2) 243-268. https:/ / doi.org/10.2190/CS.15.2.f

C,elik, H. C., Ertas, H., \& Ilhan, A. (2018). The impact of project-based learning on achievement and student views: The case of AutoCAD programming course. Journal of Education and Learning, 7(6), 67-80. https://doi.org/10.5539/jel.v7n6p67

Coruhly, T. S. \& Nas, S. E. (2018). The impact of project-based learning environments on conceptual understanding: The "recycling" concept. Asia-Pacific Forum on Science Learning and Teaching, 19(1). https://www.eduhk.hk/apfslt/download/v19_issue1_files/coruhlu.pdf

Das, A. K., Nguyen, Q. Y., Nguyen, A. T., Nomikoudis, M., \& Van, D. H. (2019). Course redesign to incorporate flipped delivery: A business degree case in Vietnam. Issues in Educational Research, 29(2), 363-383. http://www.iier.org.au/iier29/das.pdf

De Graaff, E. D. \& Kolmos, A. (2003). Characteristics of problem-based learning. The International Journal of Engineering Education, 19(5), 657-662. https:/ /www.ijee.ie/articles/Vol19_ 5/IJEE1450.pdf

Diehl, W., Grobe, T., Lopez, H., \& Cabral, C. (1999). Project-based learning: A strategy for teaching and learning. Boston, MA: Center for Youth Development and Education, Corporation for Business, Work, and Learning.

Everett, M. C. (2013). Reflective journal writing and the first-year experience. International Journal of Teaching and Learning in Higher Education, 25(2), 213-222. https:/ / eric.ed.gov/?id=EJ1016545

Fini, E. H., Awadallah, F., Parast, M. M., \& Abu-Lebdeh, T. (2018). The impact of project-based learning on improving student learning outcomes of sustainability concepts in transportation engineering courses. European Journal of Engineering Education, 43(3), 473-488. https://doi.org/10.1080/03043797.2017.1393045

Fink. D. L. (2013). Creating significant learning experiences. San Francisco, CA: Jossey-Bass

Gall, M. D., Gall, J. P., \& Borg, W. R. (2006). Educational research: An introduction (8 ${ }^{\text {th }}$ ed). Boston, MA: Allyn \& Bacon

Gonyea, R. M. (2005). Self-reported data in institutional research: Review and recommendations. New Directions for Institutional Research, 127, 73-89. https://doi.org/10.1002/ir.156

Hearne, J. L. \& Henkin, A. B. (2011). Enabling initiative and enterprise: Faculty-led course redesign in a STEM discipline. Educational Research Quarterly, 35(1), 34-64. https://eric.ed.gov/?id=EJ964928

Huysken, K., Olivey, H., McElmurry, K., Gao, M., \& Avis, P. (2019). Assessing collaborative, project-based learning models in introductory science courses. Journal of the Scholarship of Teaching and Learning, 19(1), 6-28. https://doi.org/10.14434/josotl.v19i1.26777

Hoops, L. D. \& Artrip, A. (2016). College student success course takers' perceptions of college student effectiveness. Learning Assistance Review, 21(2), 55-67. https://eric.ed.gov/?id=EJ1114471

Karp, M. M., Raufman, J., Efthimiou, C. \& Ritze, N. (2017). Revising a college 101 course for sustained impact: Early outcomes. Community College Journal of Research and Practice, 41(1), 42 55. https://doi.org/10.1080/10668926.2016.1152929

Krajcik, J. S., Blumenfeld, P. C., Marx, R. W., Bass, K. M., Fredricks, J., \& Soloway, E. (1998). Inquiry in project-based science classrooms: Initial attempts by middle school students. The Journal of the Learning Sciences, 7, 313-350.

https://www.jstor.org/stable/1466790?seq=1\#page_scan_tab_contents

Journal of the Scholarship of Teaching and Learning, Vol. 21, No. 2, June 2021. josotl.indiana.edu 
Lynch, D. J. (2006). Motivational strategies, learning strategies, and resource management as predictors of course grades. College Student Journal, 40(2), 423-428.

https://eric.ed.gov/?id=EJ765340

Moursund, D. (1999). Project-based learning using information technology. Eugene, OR: International Society for Technology in Education.

Murray, J., \& Lachowsky, N. J. (2016). Changes in first-year students' use of research resources: Impacts of an interdisciplinary seminar program on research and literacy learning outcomes. The Canadian Journal for the Scholarship of Teaching and Learning, 8(3). https://doi.org/10.5206/cjsotl-rcacea.2017.3.13

National Resource Center. (2019). 2017 National Survey on The First-Year Experience. https://nrcfye.presswarehouse.com/browse/book/9781942072324/2017-National-Surveyon-The-First-Year-Experience

Nomme, K. \& Birol, G. (2014). Course redesign: An evidence-based approach. The Canadian Journal for the Scholarship of Teaching and Learning, 5(1). http://ir.lib.uwo.ca/cjsotl_rcacea/vol5/iss1/2

Olson, J. S. (2017). Helping first-year students get grit: The impact of intentional assignments on the development of grit, tenacity, and perseverance. Journal of The First-Year Experience \& Students in Transition, 29(1), 99-118. https://eric.ed.gov/?id=EJ1139399

Pardue, K.T. \& Morgan, P. (2008). Millennials considered: A new generation, new approaches, and implications for nursing education. Nursing Education Perspectives, 29(2), 74-79. https://www.ncbi.nlm.nih.gov/pubmed/18459621

Permzadian, V., \& Crede, M. (2016). Do first-year seminars improve college grades and retention? A quantitative review of their overall effectiveness and an examination of moderators of effectiveness. Review of Educational Research, 86(1), 277-316. https://doi.org/10.3102/0034654315584955

Pittendrigh, A., Borkowski, J., Swinford, S., \& Plumb, C. (2016). Knowledge and community: the effect of a first-year seminar on student persistence. The Journal of General Education, 65(1), 48-65. https://muse.jhu.edu/article/626139

Requies, J. M., Agirre, I., Barrio, V. L., \& Graells, M. (2018). Evolution of project-based learning in small groups in environmental engineering courses. Journal of Technology and Science Education, 8(1): 45-62. https://doi.org/10.3926/jotse.318

Rickes, P.C. (2009). Make way for Millennials! How today's students are shaping higher education space. Planning for Higher Education, 37(2), 7-17. https:// eric.ed.gov/?id=EJ831268

Rosenthal, D., \& Weitz, R. (2012). Large-course redesign via blended learning: A postimplementation assessment across institutions. International Journal on E-Learning, 11(2), 189207. https:// eric.ed.gov/?id=EJ972182

Ryan, M. G. (2013) Improving retention and academic achievement for first-time students at a twoyear college. Community College Journal of Research and Practice, 37(2), 131-134, https://doi.org/10.1080/10668926.2012.715266

Saliba, R., Mussleman, P., Fernandes, M., \& Bendriss, R. (2017). Promoting information literacy of pre-medical students through project-based learning: A pilot study. International Journal of Education and Literacy Studies, 5(4), 1-15. https:/ files.eric.ed.gov/fulltext/EJ1160652.pdf

Shaw, S. \& Fairhurst, D. (2008). Engaging a new generation of graduates. Education \& Training, 50(5), 366-378. https://eric.ed.gov/?id=EJ801305

Stebleton, M. J., \& Jehangir, R. (2016). Creating communities of engaged learners: An analysis of a first-year inquiry seminar. Learning Communities Research and Practice, 4(2). http://washingtoncenter.evergreen.edu/lcrpjournal/vol4/iss2/5

Steenhuis, H. J. \& Rowland, L. (2018). Project-based learning: How to approach, report, present, and learn from course-long projects. New York, NY: Business Expert Press

Journal of the Scholarship of Teaching and Learning, Vol. 21, No. 2, June 2021.

josotl.indiana.edu 
Steiner, H. H., Trivedi, N. H., \& Brown, J. A. (2019). Bringing a learning strategies project to scale in a first-year seminar. Journal of Effective Teaching in Higher Education, 1(2). $27-44$. https:/ / files.eric.ed.gov/fulltext/EJ1214933.pdf

Sternberg, R. J. (2008). Interdisciplinary problem-based learning: An alternative to traditional majors and minors. Liberal Education, 94(1), 12-17. https:// eric.ed.gov/?id=EJ790438

Swanson, N. M., Vaughan, A. L. \& Wilkinson, B. D. (2017). First-year seminars: supporting male college students' long-term academic success. Journal of College Student Retention: Research, Theory \& Practice, 18(4) 386-400. https://doi.org/10.1177/1521025115604811

Tampke, D. R., \& Durodoye, R. (2013). Improving academic success for undecided students: a firstyear seminar/learning community approach. Learning Communities Research and Practice, 1(2). https:/ / eric.ed.gov/?id=EJ1112851

Thomas, J. W. (2000). A review of research on project-based learning. http://www.bobpearlman.org/BestPractices/PBL_Research.pdf

Vaughan, N. D. (2010). A blended community of inquiry approach: Linking student engagement and course redesign. Internet and Higher Education, 13(1), 60-65. https://doi.org/10.1016/j.iheduc.2009.10.007

Vaughan, A., Parra, J. \& Lalonde, T. (2014). First-generation college student achievement in the first-year seminar: a quasi-experimental design. Journal of the First-Year Experience \& Students in Transition, 26(2), 51-67. https://eric.ed.gov/?id=EJ1047352

Wiggins, G. (1998). Educative assessment: Designing assessments to inform and improve performance. San Francisco: Jossey-Bass.

Wilson, D. A., Dondlinger, M. J., Parsons, J. L., \& Niu, X. (2018). Exploratory analysis of a blendedlearning course redesign for developmental writers. Community College Journal of Research and Practice, 42(1), 32-48. https://doi.org/10.1080/10668926.2016.1264898

Woolfork-Barnes, T. (2017). Seven-year (2007-2013) retention study on students enrolled in thematic and nonthematic first-year experience seminar courses. Strategic Enrollment Management Quarterly, 5(3), 118-127. https://doi.org/10.1002/sem3.20110

Wise, A. F., \& Shaffer, D. W. (2015). Why theory matters more than ever in the age of big data. Journal of Learning Analytics, 2(2), 5-13. http://dx.doi.org/10.18608/jla.2015.22.2 